\title{
MINERALOGY, GEOCHEMISTRY, AND SEQUENTIAL EXTRACTION EXPERIMENT OF REE IN WEATHERED ANGGI GRANITE, MANOKWARI REGENCY, WEST PAPUA, INDONESIA
}

\author{
Ega Gita Prasastia, Lucas Donny Setijadji, and I Wayan Warmada \\ Department of Geological Engineering, Gadjah Mada University, Yogyakarta, Indonesia
}

\begin{abstract}
This research objective is to identify geochemical and mineralogical characteristics of Rare earth elements (REE) in the weathering products of Anggi Granite, which is located in Manokwari Regency, West Papua, Indonesia. The research is conducted on 7 samples of fresh rocks and 7 samples of weathered rocks of Anggi Granite. The research analysis consists of petrography, XRD, XRF, and sequential extraction experiment, supported by secondary data and references. Anggi Granite is S-type and peraluminous granite that contains zircon, monazite and apatite as a rare earth bearing minerals. Weathering products of Anggi Granite do not have a significant enrichment of REE, even some of the samples are depleted in REE. REE in weathered Anggi Granite are dominantly present in the primary minerals, mostly in zircon and monazite. Extractable form of geochemical fractions include crystalline Fe-oxide occluded fraction (ilmenite, hematite and goethite), and ion-exchangeable (illite, kaolin and chlorite). Enrichment of REE in the weathered Anggi Granite is influenced by the presence of resistant REEbearing minerals, in the forms of zircon and monazite, degree of weathering related to the presence of secondary minerals, and other factors such as $\mathrm{pH}$ and Eh.
\end{abstract}

${ }^{*}$ Corresponding author: E.G. PRASASTIA, Department of Geological Engineering, Gadjah Mada University. Jl. Grafika 2 Yogyakarta, Indonesia. E-mail: egagitap@gmail.com
Keywords: Anggi Granite, REE, Weathering, Sequential extraction experiment, Geochemical fraction

\section{Introduction}

Rare earth elements (REE) is a group of elements which consist of Lanthanide group with yttrium (Y) (Castor and Hedrick, 2006), although some writer also classify scandium (Sc) as REE. Lanthanide is a group of elements with similar behavior and hardly separated from each other. It consists of lanthanum (La), cerium (Ce), praseodymium (Pr), neodymium $(\mathrm{Nd})$, promethium $(\mathrm{Pr})$, samarium $(\mathrm{Sm})$, europium $(\mathrm{Eu})$, gadolinium $(\mathrm{Gd})$, terbium $(\mathrm{Tb})$, dysprosium (Dy), holmium (Ho), erbium (Er), thulium $(\mathrm{Tm})$, ytterbium $(\mathrm{Yb})$, and lutetium $(\mathrm{Lu})$. Yttrium $(\mathrm{Y})$ is also classified as REE because of the similarity in behavior and occurrence with Lanthanide (Castor and Hedrick, 2006).

REE have many applications in recent modern industry. The followed consequences are the high necessity of REE, so it has high economical price. REE exploration was done, and it is known that REE deposits consist of iron-REE deposits, carbonatite, laterite, placer, vein and peralkaline igneous rocks (Castor and Hedrick, 2006). REE have a big atomic radius and charge, which make it difficult to re- 
place the major elements during magma crystallization (Mason and Moore, 1982), so it will has higher concentration in late crystallized igneous rocks, or rocks with further differentiation processes (Henderson, 1986). Granitic rock is a potential rock that contains high amounts of REE. Weathering processes in granitic rock result the enrichment of REE concentration as laterite deposit (Bao and Zhao, 2008).

Anggi Granite in West Papua is one of the granitic rocks in Indonesia which could have a high potential of REE. It is located in Anggi District, Manokwari Regency, West Papua, Indonesia (Figure 1). Tropical climate condition, which is typical in Indonesia area, creates weathering products in the surface of the granitic rocks. In the weathering products, REE present in different geochemical form than that of in fresh rocks. REE can present in primary minerals, or dissolved then bonded by secondary minerals or leached to other parts of the soils, which also affect the enrichment of REE. Mineralogy and geochemistry of rare elements, therefore become an important factor to analyze the potential and mineral target of REE in the weathered Anggi Granite. The controlling factors in the REE enrichment and characteristics of REE in the weathering products, especially in granite is also studied.

\section{Geologic setting}

The geology of West Papua generally consists of metamorphic rocks as a basement, known as Kemum Formation, intruded by some plutonic rocks, which are overlaid by some formations of pyroclastic and sedimentary rocks (Pieters et al., 1990). Those plutonic rocks consist of Melaiurna Granite, Maransabadi Granite, Kwatisore Granite, Wariki Granodiorite, Warjori Granite, Netoni Intrusive Complex, and Anggi Granite. The three later are located along Sorong Fault Zone in the eastern part of West Papua Bird's Head.

Anggi Granite, which become the concern in this research, present in form of three intrusive bodies, consists of Didohu, Testega and Neney Granites, which is mentioned by Sarira (2013). Anggi Granite intruded Kemum For- mation and was been overlaying by Wai and Befoor Formation (Pieters et al., 1990). Anggi Granite is dominated by muscovite and biotite granite, but quartz diorite, aplite and pegmatite are also found locally (Pieters et al., 1990). Petrogenetic research of Anggi Granite by Sarira (2013) proved that Anggi Granite is a peraluminous S-type granite. From K-Ar dating by Bladon (1998, vide Pieters et al., 1990), the age of Anggi Granite ranges from 227 to $248 \mathrm{Ma}$, whereas according to Harahap et al. (1998) it has the age of 227-295 Ma.

\section{Methods}

The analysis of this research was done on fresh rocks and weathered samples of Anggi Granite. The samples was taken from eight (8) location, which is located on the outcrop of Anggi Granite intrusive bodies, consist of Didohu Anggi Granite (sample JNS-AG 1.2), Testega Anggi Granite (samples JNS-AG 2.3, JNS-AG 2.4, JNSAG 2.8, and JNS-AG 2.9), and Neney Anggi Granite (samples JNS-AG 3.1 and JNS-AG 3.2). Figure 1 showed the samples location in the research area. One sample of fresh rock and one sample of weathering product were taken in each location to be analyzed.

All samples were analyzed by ICP-MS method, conducted in Activation Laboratories, Canada to elucidate the composition of REE in each sample. Fresh rock samples were analyzed by polarizing light microscope to understand the texture and composition of the rocks, especially the presence of REE-bearing accessory minerals. Furthermore, X-ray Diffraction (XRD), petrographic analysis, X-Ray Fluorescence $(\mathrm{XRF})$ and a sequential extraction based to Miller et al. (1986) with modification have been conducted in the Faculty of Engineering, Kyushu University, Japan.

\section{Results and discussion}

\section{Mineralogy and weathering process of Anggi Granite}

Mineralogical composition of Anggi Granite consists of quartz, orthoclase and plagioclase 

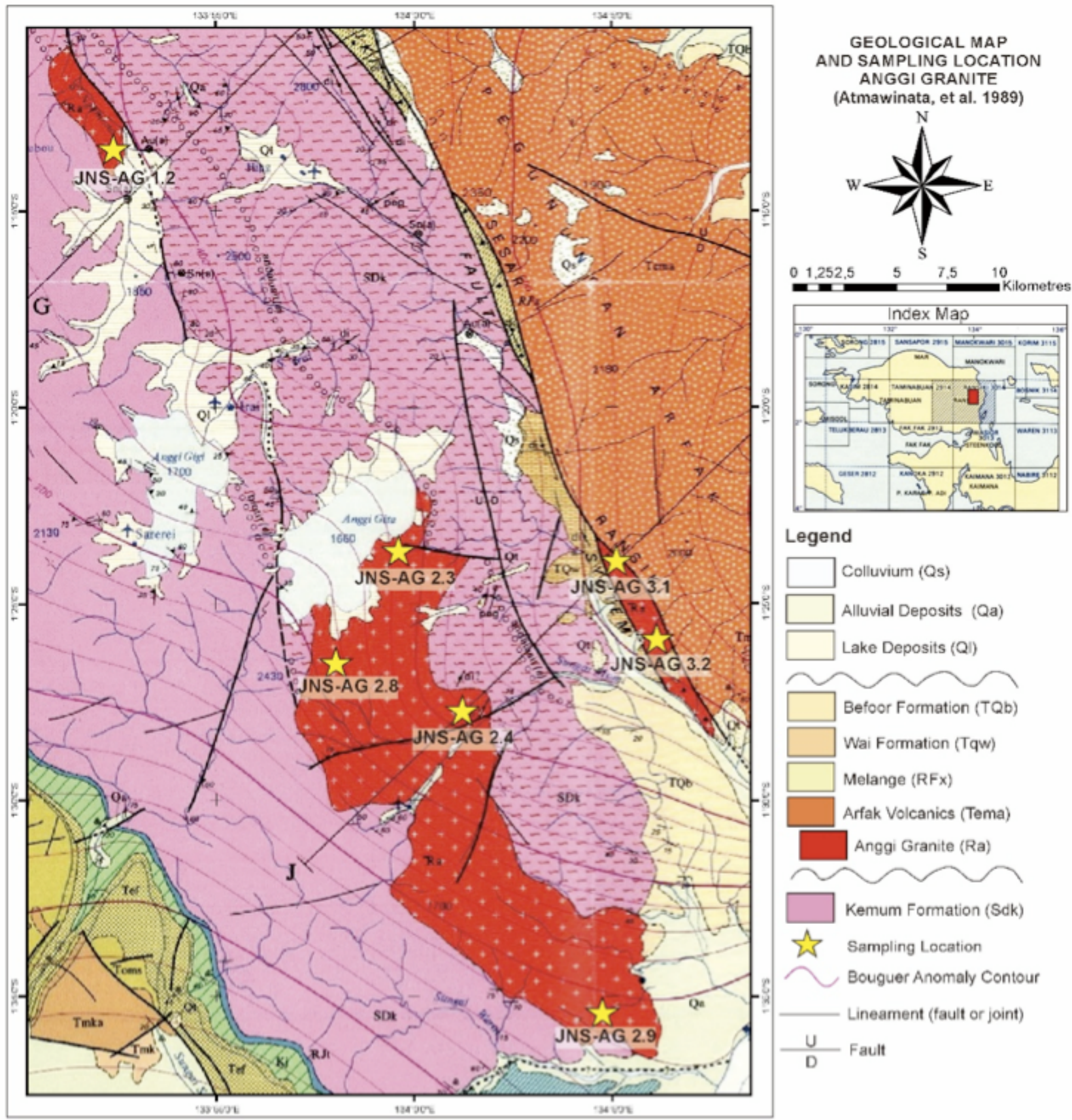

Legend
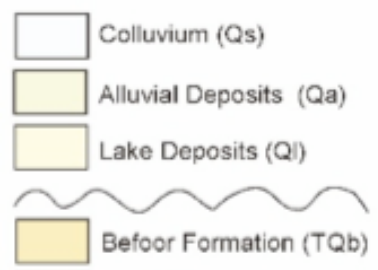

Wai Formation (Tqw) Melange (RFx)

Arfak Volcanics (Tema) Anggi Granite (Ra)

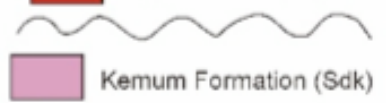

Sampling Location

Bouguer Anomaly Contour - Lineament (fault or joint)
$\frac{U}{D}$

Figure 1: Geological map and sample location of Anggi Granite (Atmawinata et al., 1989, by modification). Anggi Granite consists of Didohu Granite (in the top part of the map), Testega Granite (the biggest intrusive body in the bottom part of the map) and Neney Granite (in the right part of the map). 
with various abundances, while accessory minerals dominated by muscovite and/or biotite. REE-bearing accessory minerals presents as zircon and monazite in all rock samples, whereas apatite is only found in one sample (JNS-AG $1.2 \mathrm{R}$ ) (Table 1). The observation of weathered rock sample of Anggi Granite, as well as the calculation of CIA (Chemical Index of Alteration) (Nesbitt and Young, 1982 vide Bao and Zhao, 2008) showed that Anggi Granite was not intensively weathered. Sample JNS-AG 2.9 S has the biggest CIA value, followed by JNS-AG $2.8 \mathrm{~S}$, JNS-AG 1.2 S, JNS-AG 2.3 S, JNS-AG 2.4 S, JNSAG 3.2 S, and the last one is JNS-AG 3.1 S.

Petrography and XRD analysis shows that weathered products of Anggi Granite still contain primary minerals of the fresh rocks, such as quartz, orthoclase, plagioclase, muscovite and biotite, although the amount of these minerals, except quartz, decrease significantly. Monazite and zircon are also still presence, but apatite is no longer exist (Table 2). Secondary minerals as a result of weathering present as clay minerals, such as illite and kaolin, with high intensity in samples JNS-AG 1.2 S and JNS-AG 2.8 $\mathrm{S}$. Fe-oxide is also commonly presence as a replacement of biotite, whereas goethite present in sample JNS-AG $2.9 \mathrm{~S}$.

\section{REE Mineralogy}

REE can present in granitic rock in relatively big proportion, compared to other igneous rock, except for pegmatite and carbonatite, which contain large proportion of REE (Henderson, 1986; Castor and Hedrick, 2006). The proportion of REE is related to the differentiation process of the igneous rock (Henderson, 1986). Except for quartz, all of the primary minerals in igneous rocks, especially granitic rocks, contain REE in various proportions. However, REE are more concentrated in the accessory minerals such as sphene, apatite, zircon and monazite (Henderson, 1986; Yusoff, et al., 2013). In the case of Anggi Granite, accessory minerals consist of apatite, monazite and zircon (Table 1) and REE will dominantly consist in those accessory minerals.

During the weathering process, primary and accessory minerals which contain REE will dis- solve and secondary minerals are formed. REE that is freed from primary minerals during weathering processes then makes a bond with secondary minerals. Secondary minerals tie REE with different process and depend on the chemical and structural composition (Yusoff et al., 2013). Sequential extraction analysis was done to separate heavy metals, including REE, from each geochemical fraction, thus elucidate the dominant geochemical form of REE in the soil. In the sequential extraction analysis of Anggi Granite, extractable REE consist only of $20.1-36.8 \%$ from total REE in the weathered rock samples, and the non-extractable part $(63.2-79.9 \%)$ include in the residual form (Figure 2). REE in the residual form is incorporated in the stable crystal structure of minerals, particularly primary minerals which have not been destroyed or changed during weathering process.

The abundances of REE in residual minerals are generally caused by non-intensive weathering process in the rock. Less resistant REE-bearing minerals will be weathered more quickly than the more resistant one. Zircon and monazite are very resistant REE-bearing minerals (Bao and Zhao, 2008). Both of them are present in fresh rock samples in significant amount, and still existing with similar abundances in the weathering samples, proved by polished section analysis (Table 2). From this result, it can be assumed that REE in weathering samples of Anggi Granite also dominantly consist in zircon and monazite as residual form.

The extractable fractions are dominated by crystalline Fe-oxide occluded and ionexchangeable fractions. Crystalline Fe-oxide minerals consist of ilmenite, hematite and goethite, which can take a role in containing REE in the weathering samples. Cerianite, which have similar stability field with goethite (Braun et al., 1990) are extracted in this phase and also some portion of amorphous Fe-oxide minerals, thus will increase REE concentration in this fraction. In the other hand, amorphous Fe-oxide and Mn-oxide fractions, which in some literature (Tessier et al., 1999; Filgueiras et al., 2002) belong to the same group with crys- 
Table 1: Abundances of primary and accessory minerals in Anggi Granite samples, based on petrographic analysis (units in \%).

\begin{tabular}{|l|c|c|c|c|c|c|c|}
\hline & $\begin{array}{c}\text { JNS-AG } \\
1.2 \mathrm{R}\end{array}$ & $\begin{array}{c}\text { JNS-AG } \\
2.3 \mathrm{R}\end{array}$ & $\begin{array}{c}\text { JNS-AG } \\
2.4 \mathrm{R}\end{array}$ & $\begin{array}{c}\text { JNS-AG } \\
2.8 \mathrm{R}\end{array}$ & $\begin{array}{c}\text { JNS-AG } \\
2.9 \mathrm{R}\end{array}$ & $\begin{array}{c}\text { JNS-AG } \\
3.1 \mathrm{R}\end{array}$ & $\begin{array}{c}\text { JNS-AG } \\
3.2 \mathrm{R}\end{array}$ \\
\hline Quartz & 22 & 33 & 27 & 32 & 30 & 28 & 29 \\
\hline K-feldspar & 18 & 23 & 36 & 29 & 34 & 37 & 35 \\
\hline Plagioclase & 10 & 20 & 22 & 18 & 22 & 18 & 28 \\
\hline Microcline & 22 & - & - & - & - & - & - \\
\hline Biotite & - & 12 & 8 & 11 & - & 10 & - \\
\hline Muscovite & 6 & 9 & 5 & 5 & 12 & 5 & 6 \\
\hline Hornblende & 12 & - & - & - & - & - & - \\
\hline Garnet & 2 & $<1$ & - & 3 & - & - & - \\
\hline Opaque mineral & 1 & 1 & 1 & 1 & 1 & 1 & 1 \\
\hline Apatite & 6 & 1 & - & - & - & - & - \\
\hline Monazite & $<1$ & $<1$ & $<1$ & $<1$ & $<1$ & $<1$ & $<1$ \\
\hline Zircon & $<1$ & $<1$ & $<1$ & $<1$ & $<1$ & - & - \\
\hline & & & & & & & \\
\hline Rock's mame & $\begin{array}{l}\text { Hornblen- } \\
\text { de granite }\end{array}$ & $\begin{array}{c}\text { Biotite } \\
\text { granite }\end{array}$ & Granite & Granite & $\begin{array}{c}\text { Muscovite } \\
\text { granite }\end{array}$ & $\begin{array}{c}\text { Biotite } \\
\text { granite }\end{array}$ & Granite \\
\hline
\end{tabular}

Table 2: Abundances of primary and accessory minerals in weathered Anggi Granite samples, based on petrographic analysis.

\begin{tabular}{|l|c|c|c|c|c|c|c|}
\hline & JNS-AG & JNS-AG & JNS-AG & JNS-AG & JNS-AG & JNS-AG & JNS-AG \\
$2.2 \mathrm{~S}$ & $2.3 \mathrm{~S}$ & $2.4 \mathrm{~S}$ & $2.8 \mathrm{~S}$ & $2.9 \mathrm{~S}$ & $3.1 \mathrm{~S}$ & $3.2 \mathrm{~S}$ \\
\hline Quartz & ++++ & ++++ & ++++ & ++++ & ++++ & ++++ & ++++ \\
\hline K-feldspar & +++ & ++++ & +++ & +++ & +++ & +++ & ++++ \\
\hline Plagioclase & ++ & ++ & ++ & ++ & ++ & +++ & ++ \\
\hline Microcline & ++ & - & - & - & - & - & - \\
\hline Biotite & - & ++ & ++ & ++ & - & + & ++ \\
\hline Muscovite & ++ & + & - & + & - & - & - \\
\hline Hornblende & - & - & - & - & - & - & - \\
\hline Garnet & - & - & - & - & - & - & - \\
\hline Opaque mineral & + & + & + & + & + & + & + \\
\hline Apatite & - & - & - & - & - & - & + \\
\hline Monazite & + & + & + & + & + & + & + \\
\hline Zircon & + & + & + & + & + & - & + \\
\hline Fe-oxide & + & ++ & ++ & ++ & +++ & ++ & - \\
\hline
\end{tabular}

Note: $(++++)=$ very abundant; $(+++)=$ abundant; $(++)=$ not abundant; $(+)=$ rare; $(-)=$ not appear. 


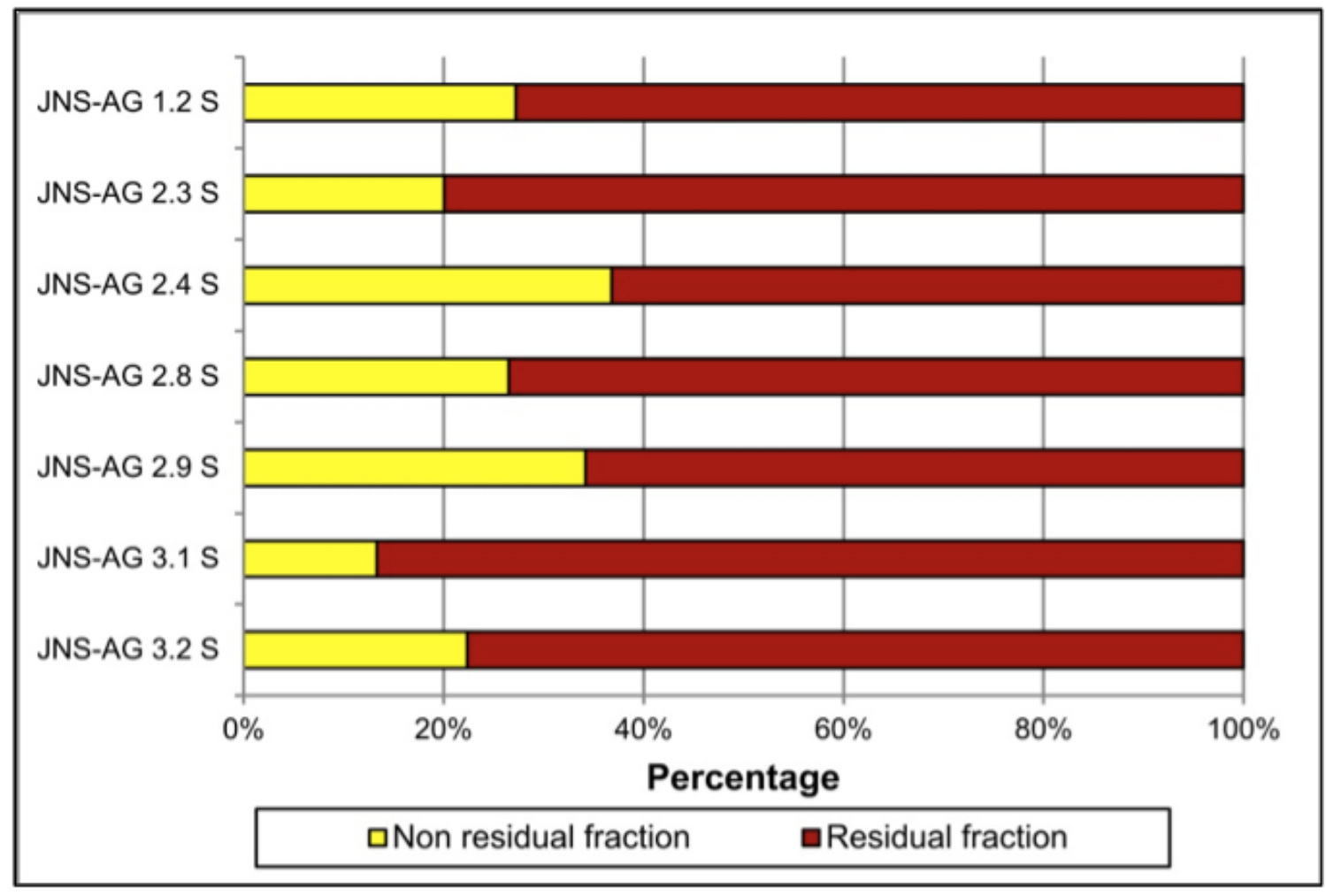

Figure 2: Percentage of residual fraction in weathering samples of Anggi Granite from sequential extraction analysis.

talline Fe-oxide, only contain small amount of REE.

Ion-exchangeable fraction dominantly is contained only in sample JNS-AG $1.2 \mathrm{~S}$ and JNSAG $2.8 \mathrm{~S}$. Both samples are characterized by high CIA values, and also the presence of clay minerals. Samples JNS-AG $3.1 \mathrm{~S}$ and JNSAG $3.2 \mathrm{~S}$ which have small CIA values almost do not contain ion-exchangeable fraction. Figure 3 presents the relation between degrees of weathering with the intensity of REE in ionexchangeable fraction, which shows the similar pattern. Meanwhile, sample JNS-AG 2.9 S which has similar CIA values with JNS-AG 1.2 $\mathrm{S}$ and JNS-AG 2.8 S do not contain a significant amount of ion-exchangeable fraction. Apart from that, ion-exchangeable fraction is sensitive to $\mathrm{pH}$ change (Hu et al., 2008). The acid $\mathrm{pH}$ condition in JNS-AG $2.9 \mathrm{~S}$ will easily break the cation bond of ion-exchangeable fraction.

Clay minerals generally act as ionexchangeable (Hu et al., 2008), which in Anggi Granite samples consist of illite, chlorite and kaolin. Ion-exchangeable fraction more readily adsorbs LREE than HREE (Yusoff et al., 2013), since LREE affinity to clay minerals is higher than HREE (Bao and Zhao, 2008). However, HREE can contain in high amount in this fraction when it is abundant in the weathering soil (Bao and Zhao, 2008), which result in the relative enrichment of HREE in sample JNS-AG 2.8 S.

The other fractions which contain REE in the samples, although only in small percentage, are acid soluble and organically bound fractions. Acid soluble fraction more well-known as a carbonate fraction (Tessier et al., 1979; Hu et al., 2006; Okoro et al., 2012) because carbonate $\left(\mathrm{CO}_{3}^{2-}\right)$ become the main ion which make a bond with metal ions in this fraction (Filgueiras et al., 2002). This fraction is not commonly present in the weathering soil (Hu et al., 2006). The forming of this fraction is also highly influenced by $\mathrm{pH}$ (Filgueiras et al., 2002). If the equilibrium condition to create this fraction is not available, concentration of this fraction will not significant to attract REE in high concentration, which might happen in this research. 


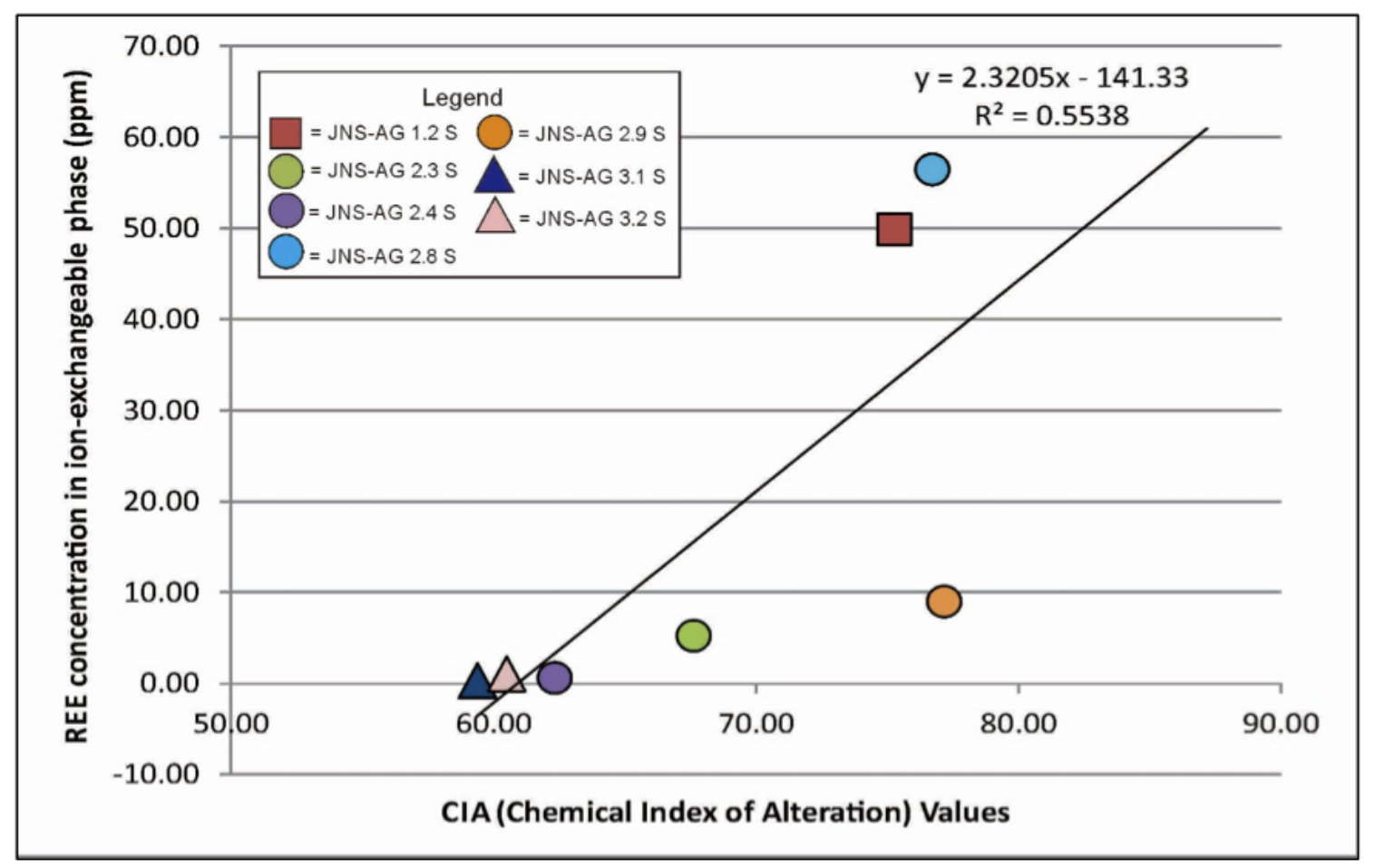

Figure 3: Graphic of relationship between degree of weathering (represent by CIA values) and REE contents in the ion-exchangeable fraction in the weathering samples of Anggi Granite.

Analyzed weathering samples in this research are taken from soil zone $C$ and not fully weathered, which result in small amount of REE in organically bound fraction. Metal in this fraction consist in organic material which generally present in soil zone A, where detritus and organism activities are commonly present (Okoro et al., 2012).

\section{Geochemical characteristics of REE in Anggi Granite}

Mass balance equation of Nesbitt (1979, vide Yusoff et al., 2013), was used with normalization on $\mathrm{Zr}$, which is considered as immobile element. The result presents that all weathered sample of Anggi Granite were depleted in REE, except for sample JNS-AG 1.2 S and JNS-AG 2.8 $\mathrm{S}$. The enrichment pattern of weathered sample also shows that JNS-AG 1.2 S and JNS-AG 2.8 S were enriched in all REE, while the other samples show different patterns (enrichment only of LREE in sample JNS-AG $2.3 \mathrm{~S}$ and JNS-AG $3.2 \mathrm{~S}$, depletion pattern in sample JNS-AG 2.4 S,
JNS-AG 3.1 S and JNS-AG 2.9 S (Figures 4 and 5).

Leaching process dominantly occurred in HREE (Gd, Tb, Dy, Ho, Er, Tm, Yb, Lu, and $\mathrm{Y})$, as it is more mobile than LREE (La, Ce, $\mathrm{Pr}$, $\mathrm{Nd}, \mathrm{Sm}$, and $\mathrm{Eu}$ ) (Bao and Zhao, 2008; Hu et al., 2006; Ma et al., 2007). Generally HREE was not much accumulated in the weathered granites with negative percentage of abundance changes (Figure 5). This is result in much greater REE fractionation in weathered samples than fresh rocks, except for JNS-AG $1.2 \mathrm{~S}$ and JNS-AG 2.8 $S$. Those two samples were enriched and had accumulation in HREE. This is due to $\mathrm{pH}$ condition, which is suitable for the deposition of REE into secondary minerals. Some ions, such as complex carbonate, also have high affinity in HREE which caused HREE mobilization and transportation to the deeper zone of weathering profile (Yusoff et al., 2013). HREE enrichment in the weathered granite can also be caused by zircon, as a HREE-bearing mineral, accumulation (Sanematsu, 2009).

LREE were enriched and accumulated more in the weathered rocks than HREE, except for 


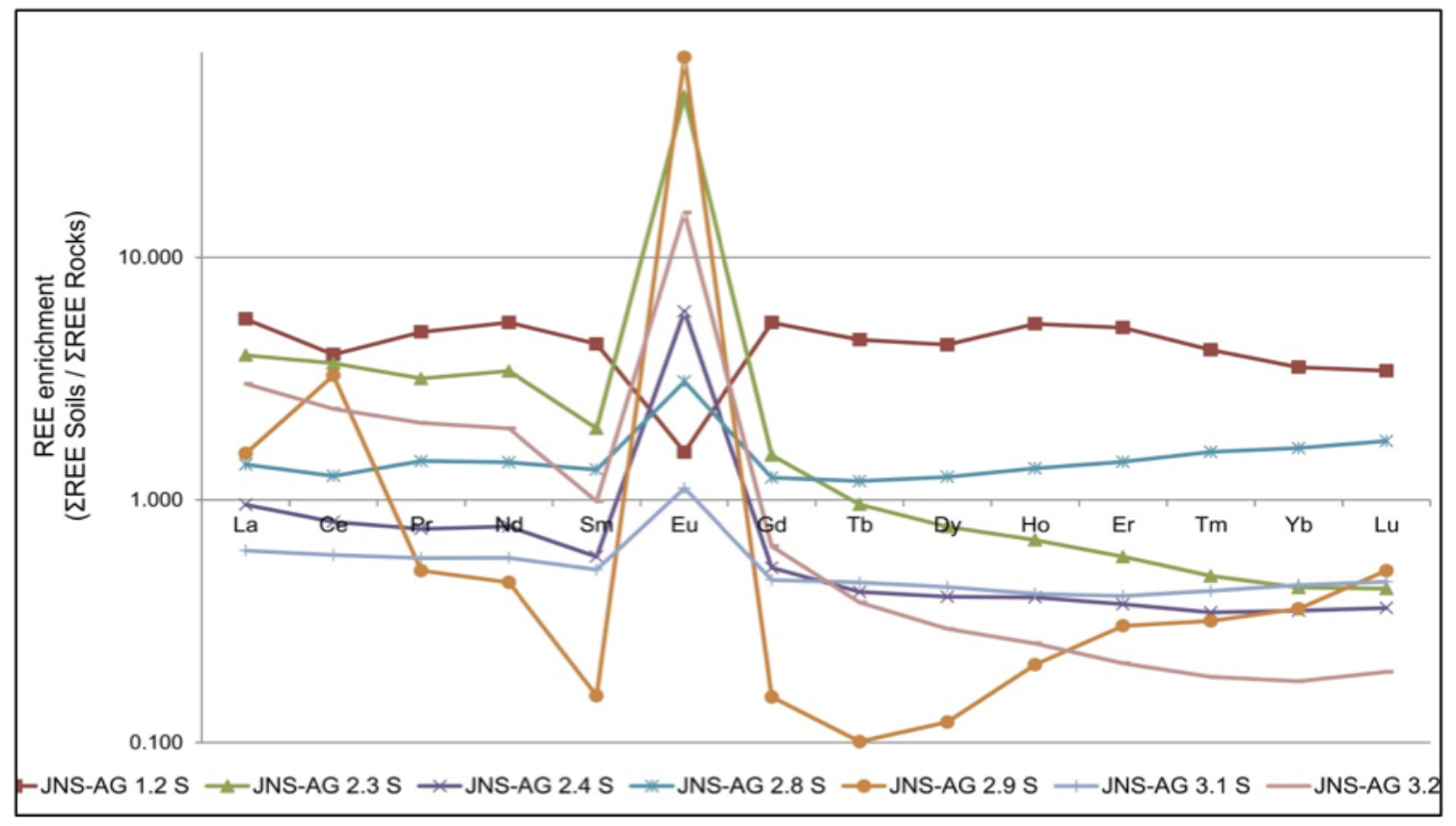

Figure 4: Spider diagram of REE normalization in the weathering products toward the fresh rocks of Anggi Granite (normalization by C1-chondrite abunandces according to McDonough and Sun, 1994).

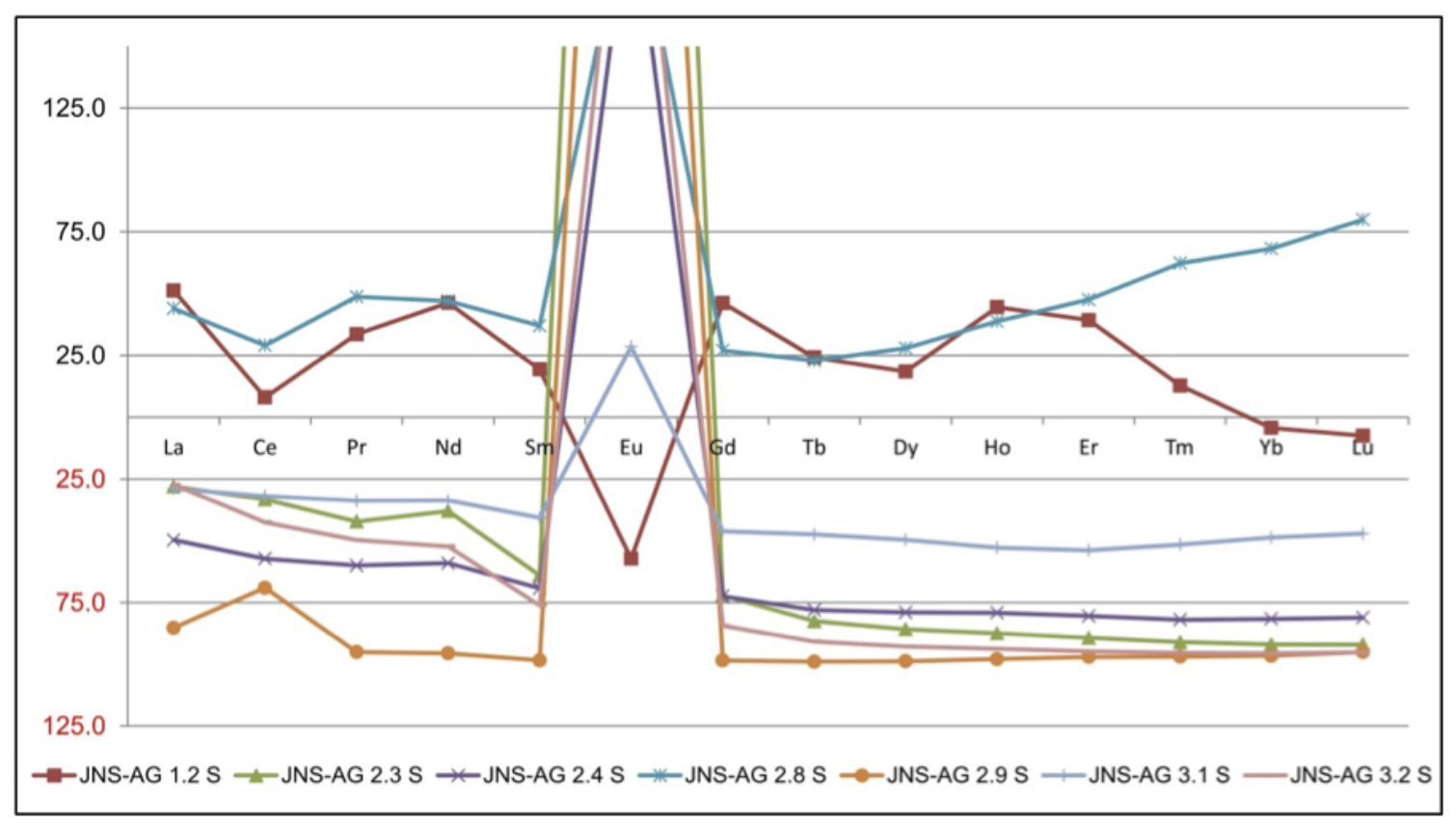

Figure 5: Spider diagram showing calculated percentage changes of rare earth elements abunandces in weathering samples of Anggi Granite, where positive and negative changes represent loss and gain respectively relative to parent rock concentration, based on mass balance calculation. In general, samples JNS-AG 1.2 S and JNS-AG 2.8 S experienced enrichment in REE, whereas the other samples have depletion pattern. 
sample JNS-AG 2.8 S. It is also shown by the increase of REE fractionation in the weathered rocks, compared to the fresh rocks. LREE was more enriched because it more compatible and will stay longer in the weathering profile. Some secondary minerals such as clay minerals and Fe-oxyhydroxide also have higher affinity for LREE (Koeppenkastrop and de Carlo, 1993; White, 2000; Compton et al., 2003 vide Yusoff $e t$ al., 2013). Positive Ce anomaly is presented in sample JNS-AG 2.9 S. Ce anomaly is caused by the difference in the oxidation value in cerium. It can present in the oxidation value $+4\left(\mathrm{Ce}^{4+}\right)$ in the oxidation state, which is relatively immobile than $\mathrm{Ce}^{3+}$ (Bao and Zhao, 2008; Braun et al., 1989; Yusoff et al., 2013), and also tend to make a bond with oxygen to create cerianite mineral (Price et al., 1991). Oxidation state in sample JNS-AG 2.9 S was supported by the presence of goethite as a secondary mineral. Braun et al. (1990) stated that environment condition for goethite to be formed is similar to cerianite, according to the $\mathrm{pH}$ and Eh values.

Meanwhile, Eu had a positive anomaly and significant enrichment in the weathered samples. In granitic rocks, Eu has a high affinity in feldspar, since it has +2 oxidation value (Henderson, 1984). Because of feldspar weathering, Eu was mobilized and accumulated in the weathering profile. Weathered sample of Anggi Granite also still contain high amount of feldspar. The accumulation of the feldspar itself can contribute to the Eu enrichment. The depletion REE pattern of Eu in sample JNS-AG $1.2 \mathrm{~S}$ can be influenced by activity of humic and flufix acid and create Eu(III)-humate complex, which is more mobile than other REE (Nagao et al., 1996; Dong et al., 2001; Wang and Dong, et al., 2001 vide $\mathrm{Hu}$ et al., 2006).

\section{Factors controlling mineralogy and geochem- istry of of REE}

Generally, there are two factors that influenced mineralogy and geochemistry of REE in weathered products of Anggi Granite: 1) geochemical characteristic and mineralogy of the rock; 2) weathering process and condition.

Different geochemical characteristics in igneous rock would create different mineralogy
(Bea, 1996). In the case of REE-bearing minerals, their presences in the rock are influenced by Alumina Saturation Index (Bea, 1996). According to Bea (1996), in peraluminous granitic rock, REE are mostly incorporated in accessory minerals, such as monazite, xenotime, zircon and apatite, which are also present in Anggi Granite samples, except for xenotime. Those minerals, except for apatite, are resistant, thus would survive in weathering process. Release of REE in the weathering products would result to REE mobilization, which would lead to REE enrichment and fractionation. In Anggi Granite this mobilization did not intensively happen, so high REE enrichment and fractionation was harder to be found, compared to metaluminous granite, which contain REE in nonresistant minerals, such as alanite.

Degree of weathering become one of the factors influencing mineralogy and geochemistry of REE in weathered granite. This research shows a relation between degree of weathering, which is shown by CIA (Chemical Index of Alteration) value, with REE enrichment (Figure 6) and fractionation (Figure 7). However, some erratic values are also found, probably due to influence of other factors, such as $\mathrm{pH}$ and Eh condition of weathering products. For example, sample JNS-AG 2.9 S does not experience significant enrichment due to leaching process in the acid $\mathrm{pH}$ environment (Figure 7). REE precipitation is highly influenced by $\mathrm{pH}$ condition except for $\mathrm{Ce}$ and $\mathrm{Eu}$, which are also influenced by oxidation state (Braun et al., 1990). In the other hand, samples JNS-AG 1.2 S and JNSAG $2.8 \mathrm{~S}$ do not have great fractionation value, because it became the accumulation place for HREE.

Weathering process would also influence the presence of secondary minerals in weathering products, for example clay minerals would more potentially occur if the degree of weathering are getting higher. Clay minerals, with its high absorption capability would bond more or less $95 \%$ of REE in the weathering products (Zhu et al., 1993 vide $\mathrm{Hu}$ et al., 2006). From sequential extraction analysis, it is known that the bonding of REE in clay minerals is correlated with REE enrichment. 


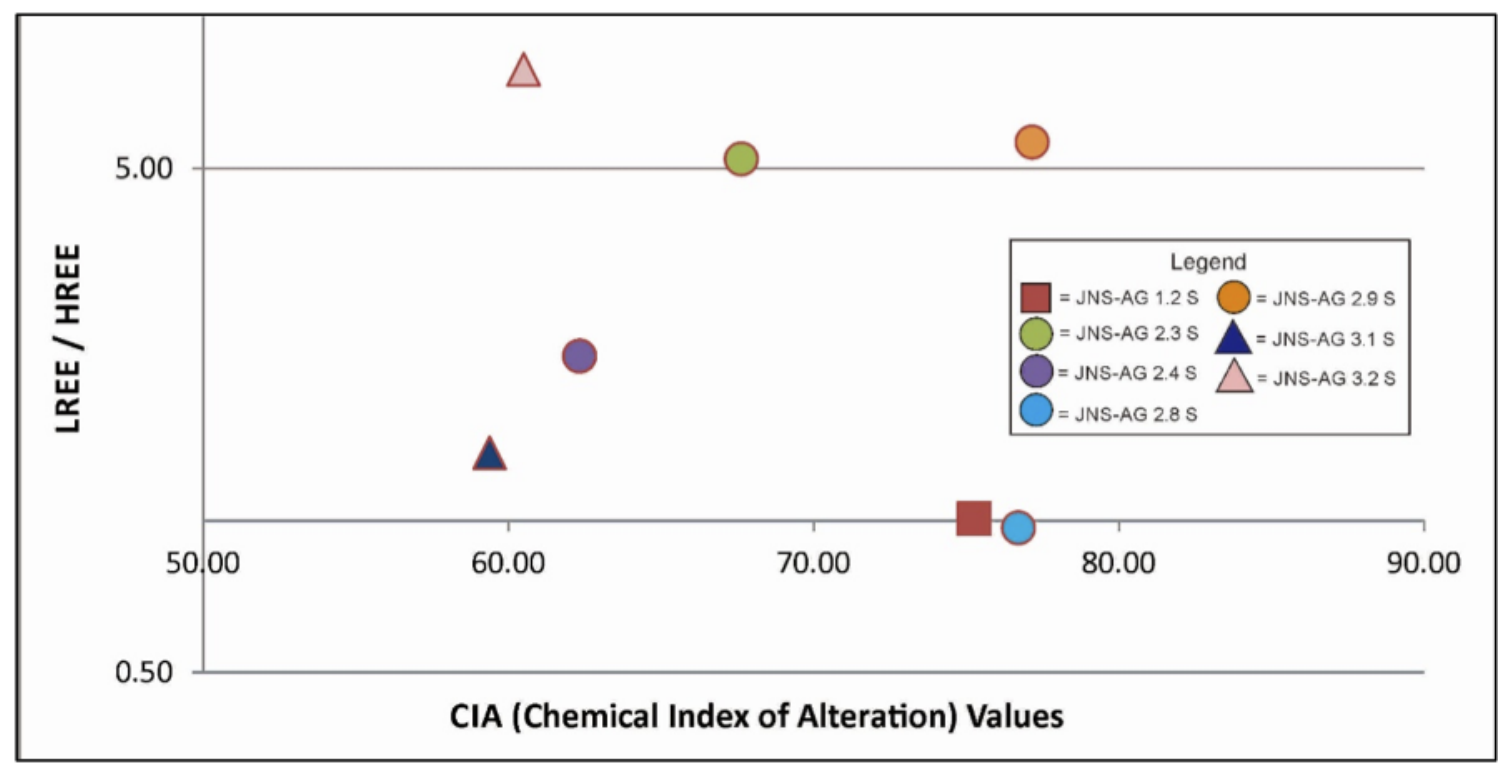

Figure 6: Plotting of CIA versus LREE/HREE ratio showing a good relationship between degree of weathering (represented by CIA values) and REE fractionation in the weathering samples of Anggi Granite.

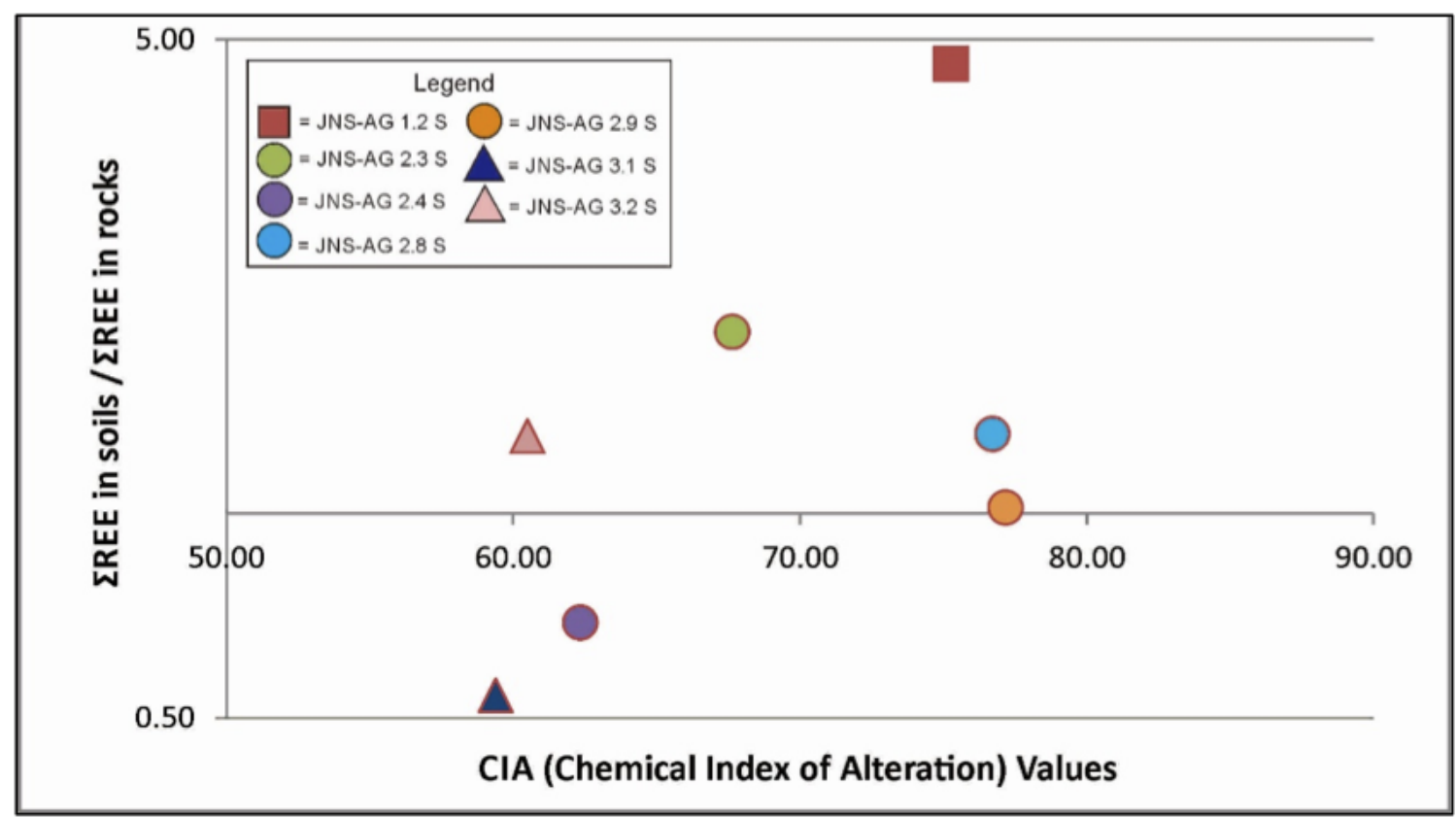

Figure 7: Plotting of CIA versus ratio of tatal REE in soils and total REE in rocks, showing a good relationship between degree of weathering (represented by CIA values) and REE enrichment in the weathering samples of Anggi Granite. 


\section{Conclusion}

The weathering products of Anggi Granite did not experience significant enrichment. REE enrichment in the samples were caused by relative enrichment in samples JNS-AG $2.3 \mathrm{~S}$ and JNS-AG 3.2 S, and absolute enrichment in samples JNS-AG 2.8 S, while the rest are depleted in REE. The absolute enrichment happen because the accumulation of REE in the reduction environment, and the depletion is caused by leaching process during weathering.

LREE/HREE values were increased in the weathering samples of Anggi Granite, because HREE were leached more than LREE, except for sample JNS-AG $1.2 \mathrm{~S}$ and JNS-AG $2.8 \mathrm{~S}$ which become the accumulation zone of HREE. Meanwhile, positive cerium anomaly occur in sample JNS-AG $2.9 \mathrm{~S}$, caused by suitable oxidation and $\mathrm{pH}$ condition for cerianite to be formed, which is characterized by the presence of goethite in the sample. REE in weathering products of Anggi Granite still dominantly contain in REE-bearing primary minerals such as zircon and monazite, while the rest consist on crystalline Fe-oxide fraction (ilmenite, hematite and goethite), and ion-exchangeable fraction (clay minerals illite, kaolin and chlorite).

Geological factors that influence the geochemical and mineralogical characteristics in the weathering samples of Anggi Granite are geochemical characterization of fresh rocks, which influences the kind of REE-bearing minerals in the rock, degree of weathering which is related to the presence of secondary minerals, especially clay minerals, and other factors related to $\mathrm{pH}$ and Eh condition.

\section{Acknowledgements}

This work was undertaken at Chemical Analysis Laboratory, X-ray Laboratory and Center of Advance Instrumental Analysis, Faculty of Engineering, Kyushu University. We thank Prof. Koichiro Watanabe for the chance given to us and Dr. Kotaro Yonezu for the helping and guidance during laboratory analysis in Kyushu University.

\section{References}

Bao, Z. dan Zhao, Z. ( 2008) Geochemistry of mineralization with exchangeable REY in the weathering crust of granitic rocks in south China. Ore Geology Reviews 33: 519-535.

Bea, F. (1996) Residence of REE, Th, and U in granites and crustals protoliths; implications for the chemistry of crustal melts. Journal of Petrology 37: 521-552.

Braun, J., Pagel, M., Muller, J., Bilong, P., Michard, A., Guillet, B. (1990) Cerium anomalies in lateritic profiles. Geochimica es Cosmochimica Acta 54: 781-795.

Castor, S. B., Hedrick, J. B. (2006) Rare Earth Elements. Industrial Minerals $7^{\text {th }}$ edition, Society for Mining, Metallurgy, and Exploration, Littleton, Colorado.

Filgueiras, A.V., Lavilla, I., Bendicho, C. (2002) Chemical sequential extraction for metal partitioning in environmental solid samples. Journal of Environment Monitoring 4: 823857.

Harahap, B.H., Hakim, A.S., Hartono, U. (1998) Upper Paleozoic-Lower Mesozoic magmatic intrusions in Western Irian Jaya. Jurnal Geologi dan Sumber Daya Mineral 8:2-13.

Henderson, P. (1986) Rare Earth Elements Geochemistry, Elsevier Science Publishers B.V., Netherlands.

Hu, Z., Haneklaus, S., Sparovek, G., Schnug, E. (2006) Rare earth elements in soils. Communications in Soil Science and Plant Analysis 37: 1381-1420.

Ma, L., Jin, L., Brantley, S.L. (2007) How mineralogy and slope aspect affect REE release and fractination during shale weathering in the Susquehanna / Shale Hills Critical Zone Observatory. Chemical Geology 290: 31-49.

Mason, B., Moore, C.B. (1982) Principles of Geochemistry. $4^{\text {th }}$ Edition, John Wiley and Sons, Inc., New York.

McDonough, W.F., Sun, S. (1995) The composition of the earth. Chemical Geology 120: 223253.

Miller, W.P., Martens, D.C., Zelazny, L.W. (1986) Effect of sequence in extraction of trace metals from soils. Soil Science Society of America Journal 50: 587-601. 
Okoro, H.K., Fatoki, O.S., Adekola, F.A., Ximba, B.J. Snyman, R.G. (2012) A review of sequential extraction procedures for heavy metals speciation in soil and sediments. Open acces scientific reports, vol. 1, issue 3.

Pieters, P.E., Hakim, A.S., Atmawinata, S. (1990) Geologi Lembar Ransiki, Irian Jaya, Pusat Penelitian dan Pengembangan Geologi, Departemen Pertambangan dan Energi, Bandung.

Price, R.C., Gray, C.M., Wilson, R.E., Frey, F.A., Taylor, S.R. (1991) The effects of weathering on rare-earth element, $\mathrm{Y}$ and $\mathrm{Ba}$ abundances in Tertiary basalts from southeastern Australia. Chemical Geology 93: 245-265.

Sanematsu, K., Murakami, H., Watanabe, Y., Duangsurigna, S., Vilayhack, S. (2009) Enrichment of rare earth elements (REE) in granitic rocks and their weathered crusts in Central and Southern Laos. Bulletin of the Geological Survey of Japan 60: 527-558.

Sarira, J.N. (2013) Petrogenesa dan Potensi Mineralisasi pada Granit Anggi, Kabupaten Manokwari, Propinsi Papua Barat, Thesis, Jurusan Teknik Geologi Universitas Gadjah Mada, Yogyakarta.

Tessier, A., Campbell, P.G.C., Bisson, M. (1979) Sequential extraction procedure for the speciation of particulate trace metals. Analytical Chemistry 7: 844-851.

Yusoff, Z.M., Ngwenya, B.T., Parsons, I. (2013) Mobility and fractionation of REEs during deep weathering of geochemically contrasting granites in a tropical setting, Malaysia. Chemical Geology 349-350: 71-86. 